this car in practice with success before $I$ removed here to take up the duties as medical officer of health of Halifax. I am, Sirs, yours faithfully,

Halifax, May 20tb, 1901. JAMES T. NEECH.

\section{"THE MEDICAL PROFESSION AND THE FRIENDLY SOCIETIES."}

\section{To the Editors of THE L $\mathrm{T}$ NOTT.}

SIRS, - No attempt seems to have been made so far in this correspondence to settle what may be considered fair remuneration for club work. Both Mr. Brabrook and "A Colliery Surgeon"--the former in THE LANCET of April 27th, p. 1232, and the latter in THE LANCET of May 11th, p. 1366-ask the question, the former rightly leaving the answer to the profession, the latter declaring himself satisfied with a payment of about $4 s$. per annum. I believe few men think that club practice pays. The beginner takes it faute de mieux and keeps it, either because the better does not come or because the resignation of his clubs would throw them into the hands of a rival practitioner or serve to introduce an opponent. Olub work is "slumped" with private work, and this "slumping" is, I contend, the main reason why the inquiry whether the former is really remunerative has not been pressed. Everybody admits that it should pay, and Mr. Brabrook places it in this respect between the attendance on the very poor and the comparatively rich.

This question of what is a proper clab payment can very obviously be approached from two directions. 1. Lêt us imagine a medical practitioner who does club work only all his life, never having or hoping to have a single private patient. What sum should he receive? What are his wants? He must have a house, servants, and all the apparatus of medical practice. He should be able to live in fairly easy circumstances. Financially, he should be at liberty to marry and it should not be accounted a misfortune if he has two or three children. It is not too much to ask that he should be able to bring up one son to his own profession and to educate his other children in a corresponding manner. He must have occasional holidays and neither he nor his family is exempt from illness and its attendant expenses. Inasmuch as the clubs will not pension him when he is too old or too infirm to work longer for them he should be able to put away something every year for his old age. I do not think this can be done on less than $£ 800$ a year. Now $£ 800$ a year means at the ordinary rate a club clientele of 4000-a number which seems unmanageable by one man. Perhaps someone with large experience of club work will tell ns how many members a medical man could attend giving all his time and doing his work well. If the sum mentioned above be accepted a simple division will show what each club member should pay a year. 2. What sum does a club medical officer actually receive for each attendance? Will "A Colliery Surgeon" and others in club practice take the trouble to divide the year's club receipts by the year's attendances (presuming they are all entered) and tell us what the quotient is? I remember hearing of one provident institution in London where this sum worked out to $2 \frac{1}{2} d$.

My own feeling is that $4 s$, a year is a ridiculously inadequate payment, and I would suggest that it should be made into a retaining fee in consideration of which the medical man should attend club patients for very small payments to be made out of a special medical fund raised by separate contribution from all the members. The surplus of this fund might be divided at the end of each year as is done with the funds of slate clubs. Of course, this is a vain suggestion as long as medical men profess themselves satisfied with the ordinary terms.

Wonersh, May 13th, 1901.

$$
\text { I am, Sirs, yours faithfully, }
$$

C. ScOTT WATSON.

\section{"HAMORRHAGIC TYPHOID FEVER."}

To the Editcrs of THE LANCET.

SIRs,-In a note on hæmorrhagic typhoid fever in THE LANCET of April 20th, p. 1156, you call attention and attach importance to the history of alcoholism in the two cases of that rare affection referred to, and express an opinion as to the probability of this factor acting as a contributory cause. From this view there can be no radical dissent, but in view of the infrequency with which the hæmorrhagic diathesis is manifested in the course of typhoid fever, even in alcoholic subjects, this influence, it seems to me, must be of most subordinate significance. It appears far more likely that the widespread and profuse hæmorrhages are to be attributed to changes in the blood or vessels, or both, induced by the infective or toxic activity, or both, of the typhoid bacilli, or as a less likely possibility by some secondary infection or intoxication. The two cases in question were reported from the Philadelphia (City) Hospital where a history of alcoholic excess is the rule and that of venereal infection is common, but even here cases similar in character to those reported are, as elsewhere, most exceptional.

I am, Sirs, yours faithfully,

Philadelphis, May 4th, 1901 AUGUSTUS A. ESHNER.

\section{"COINCIDENT TYPHOID AND MALARIAL IN FECTION." \\ To the Editors of THE LANCET.}

SIRs, - In a leading article in THE LANCET of May 18th, p. 1412, on this subject you comment on the term "typho-malarial" in connexion with some recent observations by Dr. J. P. Lyon of Buffalo, and if you will allow me I would like to draw attention to some observations of $\mathrm{my}$ own as summed up in the Alexander Prize Essay for 1881-Enteric Fever as Illustrated by Army Data at Home and Abroad. The composite word was coined by Dr. Woodward during the civil war in America to meet cases where "the attack was of a mixed character from the entrance simultaneously of both exciting agencies in the system" and by the date mentioned the name had crept into the army medical returns, but the curious feature observable was that while from the typically malarial countries no clear recognition of this hybrid disease was discernible in the statistics it figured decidedly in the returns from other stations where malarial fever was not common and where the remark appended was not uncommon that the cases of paroxysmal fever had "originated elsewhere." After pointing out that the difference in causation between the paroxysmal fevers and enteric fever was deducible even from the statistic I noted that "the onset of febrile disturbance in the tropics may simulate ague," and that "ague and enteric fever may be often combined in the sense that enteric fever may occur in a malaria-impregnated person," and this latter virus by being ronsed into activity may modify the febrile disturbance and other symptoms, and came to the opinio that while one or two cases recorded by Dr. Massy from Newera Ellia in Ceylon seemed to support the view of a simultaneous entry of the two agencies in the system at the same time, yet that the majority of the asserted hybrid cases - based on clinical data and especially temperature varia. tions to be found at the onset, mid-period, and decline of the fever-could be explained by the results of the old malarial taint or by deviations from the supposed typical temperature chart common in enteric fever in aliens in tropical conntries and also observable in the same disease at home irrespective of malarial taint. The inference I drew was much the same as that contained in the summary at the end of your article, that the term "typho-malarial" to express a distinct disease was untenable, and subsequent experience has but confirmed the conclusion that if this asserted hybrid is to be recognised in nomenclature at all its proper status is as a variety of enteric fever dependent on the prior existence of the malarial parasite in the body.

I am, Sirs, yours faithfully,

FRANCIS H. WELCH, F.R.C.S. ENG

Surgeon-Colonel (retired) Medical Staff.

Brandram-road, Lee, S.E., May 20th, 1901.

\section{PROTRACTED GESTATION.}

\section{To the Editors of THE LANCET.}

SiRs,-This morning, with some difficulty, I delivered a primipara of a male child (weight, 9 pounds 10 ounces), in every respect well developed. The last day of the mother's last period was July 2nd, 1900 - that is, 320 days from the birth of the child this morning. I have made every and all possible inquiries respecting the aforesaid dates and can thus abso. lutely confirm them. The monthly nurse was ergaged from 
April 1st. I think that this should be recorded, and thus beg you to do so. I am, Sirs, yours truly,

G. H. HAM ES, F.R.O.S. Fing.

Hertford-street, Mayfair, W., May 18th, 1901.

\section{"THE CASE OF AN ELECTION."}

\section{To the Editors of THE LANOET.}

SIRs,-I am much astonished that no reply has been forthcoming from the anthorities of the Samaritan Hospital to Dr. Shaw-Mackenzie's letter in THE LANCET of April 6th, p. 1444. The case is even stron er than Dr. ShawMackenzie puts it. I find that Dr. Shaw. Mackenzie's name appaars in the list of the staff of the Samaritan Hospital in Charchill's Medical Directory for 1901. 1 have made inquiry into the matter and I have satisfied myself that the list came to Messrs. Caurchill from the hospital in the usual way. It seems an extraordinary state of things that a man can be elected to a post and then removed from his duties without a word of explanation or regret. No "legal opinion" can possibly justify such treatment.

I am, Sirs, yours faithfully,

Upper Wimpole-street, W., May 21st, 1901.

JAMES B. BALL.

\section{THE RECENT MEETING OF THE ROYAL} COLLEGE OF PHYSICIANS OF LONDON :

\section{A CORRECTION.}

\section{To the Editars of THB LANOFT.}

SIRS, - I desire to point out that in your report of the meeting of the Comitia of the Royal College of Physicians of London in THE LANCET of May 18th, p. 1410, the name of Dr. James Taylor has been wrongly mentioned as the seconder of $\mathrm{Dr}$. Norman Moore's motion instead of my own. As a member of the Committee of Management I seconded the adoption of their report.

May 20th, 1901.

$$
\text { I am, Sirs, yours faithfully, }
$$

Frederick TAYLOR.

\section{"ROYAL ORTHOP ÆDIC HOSPITAL."}

To the Editors of THE LANOET.

Sins, - Mr. Marks has not answered the letters of the senior house surgeon of the Royal Orthopædic Hospital and of myself-in THE LANCET of April 13th, p. 1106, and March 9th, p. 739, respectively-setting forth reasons against the sale of the site. He assumed the reins of power in that institution by means of votes created for the purpose of defeating the scheme of purchase of the former committee. He holds power by the same following of votes. Under these circumstances he refuses to give reasons for suddenly changing his views and insisting upon the sale of the hospital. The objections to the sale of this valuable freehold, almost the only asset of the hospital, remain unchanged. We who have resisted the proposal to sell have increased the sums offered from $£ 28,000$ to over $£ 37000$. But we do not wish to sell and believe that removal to a leasehold in an out-of-the way quarter would be disastrous to the financial and social fature of this old-established institution. Why should Mr. Marks maintain an obstinate silence on a matter of vital importance to a public charity? Why should he write a private letter to the Editors of IHE LANCET in answer to the comments contained in the article of April 6th last, p. 1025? What has be to say to the editors of a medical journal that he cannot say to its readers? I inclose my card.

I am, Sirs, your faithfully,

May 19th, 1901. A GovernoR OF THE HospitaL.

\section{A DETAIL IN THE COSTUME OF MAYORS}

To the Editors of THE LANCET.

SIRs,-May I ask if any of your readers can inform me if the mayors of Oxford and Cambridge, should they happen to be members of the university, wear their academical hood over the offisial robe. Is it usual or correct for provincial mayors $w .10$ are also doctors of medicine to wear their hoods over their mayor's robes on official occasions?

May 20th, 1901.
DOMESTIC DRAINAGE IN PARIS.

A Householders' SYNDICATE TO Resist SANitaky REFORM.

(From our Special Correspondint.)

Domestic sanitation is making but slow progress in Paris. The sanitary authorities hoped, and thought, that the drainage of the great majority of Paris houses would be terminated by the time that the Universal Exhibition opened its doors in 1900. They did not count, however, on the tenacity, ingenuity, and avarice of the owners of house property. The reforms projected, it is true, were not of a nature to injure the interests of householders. They represented, on the contrary, what was and has been proved to be in the best interests of property owners; but they entailed a preliminary outlay, and the certainty of an immediate loss, however great might be the prospective gain, has proved a serious obstacle. Originally the sewers of Paris were not intended to receive domestic drainage. They had their outfalls into the Seine, and the river is too small and too far inland to receive the drainage of the houses. Slop-water was allowed to flow into the sewers, but the closets all drained into cesspools or into portable tubs or pails. In the course of time, however, and after endeavours extending over many years, the town bas acquired sufficient land at Gennevilliers, Achères, Triel, and Méry to receive the whole sewage of Paris, some 180000000 cubic metres per annum, and throw it on to the soil. Being thus utilised for agriculture and purified there was no longer any objection to draining the closets into the sewers. for the crude sewage was henceforth not allowed to flow into the river. The completion of these works was inaugurated on July $8 \mathrm{th}, 1899$, and they have already been described in THE LANCET. ${ }^{1}$ Simultaneously with this great work for the disposal of the sewage more sewers were built in the town and many of the old sewers were repaired or relaid. Then pressure was brought to bear upon householders so that they should substitute for their cesspools or their pails properly flushed water-closets draining direct into the sewers. By the end of the year 1890 there were only 1835 houses in Paris which were thus drained and the mortality that year was equal to $24 \cdot 1$ per 1000 of the population. In 1.893 there were 4298 houses with waterclosets and the mortality was 21.7 per 1000 . In 1896 there were 9460 houses draining direct into the sewers and the mortality was equal to 19 per 1000 inhabitants for the entire town. Of course, there were other causes that contributed to this reduction in the death-rate; but, nevertheless, there has been a notable reduction in the death-rate accompanying the improvement in domestic drainage.

At the present moment there are in all 78000 houses in Paris and of this number nearly 24,000 houses now possess water-slosets and drain direct into the sewers. For the remaining 54,000 houses there are still in existence 47913 cesspools, 21,813 tinettes filtrantes (metallic pails which while retaining the solid matter allow the liquids to flow to the sewer), and 11,909 wooden tubs or pails which retain both solids and liquids. The cesspools are supposed to be emptied once in the year and the pails removed once a week $\mathrm{or}$ oftener. When the cesspool or the pail systems are employed there is no water in the closets and no syphon traps can be applied. A pan can only be cleaned with a brush and by pouring a little water on it from a hand-jug. If much water is used the proprietors soon find this out and complain to their tenants, for they object to the cost of frequently emptying the cesspool. Under these conditions the soil-pipe is always foul and there is nothing to prevent the air from the soil-pipe and the cesspool below entering the dwelling-rooms of the house With the tinette the position is better; a larger quantity of water may be nsed since it can escape from the tinette into the sewer. The law of July 10th, 1894 sanctioned the raising of a loan by the town of Paris at 4 per cent. interest for the amount of $\$ 4.700000$. This was to be devoted to purchasing land snfficient to receive $200,000,000$ cubic metres of sewage per annum, allowing for a maximum of 40,000 cubic metres of sewage per hectare per annum. Then there was the cost of pumps and of main 